\title{
Human Rights, Islamophobia, and the War on Terrorism
}

\author{
Aidir Amin Daud \\ Department of International Law, Faculty of Law, Hasanuddin University, Indonesia. \\ E-mail: amin.daud@unhas.ac.id
}

\begin{abstract}
Declaration of Human Rights is one of the universal law products, which has become an agreement for the civilization of nations. Hence, everyone has the right to recognition everywhere as a person before the law. One of the substances of Human Rights principles is not to allow the growth of repressive attitudes from all elements in society. Including the attitude and role of the media as the guardian of human rights. This study analyzes the role of media in the production process of anti-Muslim frames, contributing to the growth of islamophobia, thereby supporting the government's repressive efforts and ignoring human rights principles. This study is a qualitative study related to the trends and challenges of islamophobia and the war on terrorism from a global perspective. The results show that islamophobia has led to the Muslim community's discrimination, exclusion, and acceptance of prejudice. This activity creates a scourge for decision-makers in many countries with numerous attributes associated with its growth. The originality of this paper exhibits a comprehensive investigation of islamophobia, international law, and terrorism. The result also showed that the media tend to discriminate due to fanaticism, violence, and terror in many extreme religious groups, thereby encouraging the spread of islamophobia.
\end{abstract}

Keywords: Islamophobia; International Law; Media Framing; Human Rights; Terrorist

\section{Introduction}

Mass media role in transmitting the dominant ideologies, beliefs, culture and values is widely accepted by media researchers and scholars. ${ }^{1}$ While Media framing (as a major theoretical model for the construction of media messages) impose limits to serve the dominant class. It molds debates in ways that eventually serve the interests of corporations. ${ }^{2}$ By doing so media fulfills dual functions, reflecting and shaping issues occurring in the cultural, social and politics. ${ }^{3}$

Nowadays, islamophobia has become an inevitable global phenomenon since the catastrophic events of 9/11. Presently, the fear of Islam and Muslims has spread worldwide due to the implementation of the US' policy "War on Terror." This policy is not only enforced in the West, it is however, executed globally. ${ }^{4}$ Furthermore, several

\footnotetext{
${ }^{1}$ Douglas Kellner, Media Spectacle and the Crisis of Democracy: Terrorism, War, and Election Battles (Routledge, 2015), p 23.

2 Khalid Sultan, "Linking Islam with Terrorism: A Review of the Media Framing since 9/11," Global Media Journal: Pakistan Edition 9, no. 2 (2016): 1-10.

3 Peter Donald Garrett and Allan Bell, "Media and Discourse: A Critical Overview," 1998, pp.1-20.

${ }^{4}$ Deepa Kumar, "Framing Islam: The Resurgence of Orientalism during the Bush II Era," Journal of Communication Inquiry 34, no. 3 (2010): 254-77.
} 
terrorist attacks in various regions of the world were linked to the fundamentalist Islamic groups. International press and statements issued by Western governments have also increasingly emphasized that Muslims are terrorists. This stereotyped Islam, irrespective of the fact that terrorists represent only a small proportion of Muslims in the world.

Presently, Islam, which is the second-largest religion globally and the Middle East, often dominates negative headlines. Islamophobia distorts the prism through which Muslims are domestically viewed thereby, leading to the proliferation of anti-Muslim rhetoric and hate crimes. In the United States and Europe, legitimate concerns for domestic security have been offset by the abuse of the anti-terrorism constitution, indiscriminate arrests, and imprisonments that compromise Muslims' civil liberties. ${ }^{5}$

The term Islamophobia ("accès de délire islamophobe") was first introduced by Etienne Dinet and Slima Ben Ibrahim in 1925. ${ }^{6}$ However, in the 1980s, it was used to state the fear of an increase in the number of Muslim immigrants from the CIS region to England. Al-Muhajiroun and the Islamic Human Rights Commission (IHRC) also used this concept to report the fears of non-Muslims towards Islam and its adherents. ${ }^{7}$ Islam is referred to as a celestial religion that brings wealth to both Muslims and the entire humanity. The Islamic da'wah mission needs to be conducted peacefully by offering grace and not hatred. However, it is understood that from inception, Islam has an aura of greatness, and therefore it is considered to have values that threaten the existence of other religions. The presence which dates back to the history of Prophet Muhammad SAW has been persecuted; however, this is Islamophobia on a small scale.

Al-Quran, a source of Islamic law, consists of positive invitations, irrespective of the fact that series of warfare were recorded in history, although they were intended to fight the enemies that wanted to destroy Islam. Perhaps for that reason, American writer Michael $\mathrm{H}$. Hart ${ }^{8}$ reported the Prophet Muhammad SAW is the number 1 or most influential figure in the history of human life. Hart reported that Isaac Newton, the scientist that proposed the theory of motion - in second place and Jesus in the third position, followed by Sidharta Gautama (Buddha), Kong Hu Cu (founder of Kong Hu Cu) and so on.

In digital world, ideologizations through face-to-face processes or through the process of value internalization previously began to move in a simpler fashion. The come into the world of the internet as a means of communication across nations created a new problem for the potential birth of new combatants from civilians. The phenomenon seems clearly in the case of ISIS (Islamic State of Iraq and Syria) ${ }^{9}$, where the ISIS fighters who claim to

\footnotetext{
${ }^{5}$ Nathan Chapman Lean and John L Esposito, The Islamophobia Industry: How the Right Manufactures Fear of Muslims (Pluto Press London, 2012), p. xv.

${ }^{6}$ Allen, Christopher, Islamophobia. Surrey: Ashgate Publishing Ltd Juergensmeyer, Mark. 1994. The New Cold War? Religious Nationalism Confronts the Secular State. London: University of California Press Ltd, 2010, 5 .

7 Renitha Dwi Hapsari, "Islamophobia Dan Tindakan Terhadap Minoritas Muslim Oleh Pemerintah Dan Kelompok 969 di Myanmar Tahun 2012-2016," Global and Policy Journal of International Relations 4, no. 2 (2016), 26-38.

${ }^{8}$ Michael H Hart, The 100: A Ranking of the Most Influential Persons in History (Citadel press, 1978).

${ }^{9}$ ISIS is the English acronym for the Islamic State in Iraq and the Levant, a Sunni jihadist group whose sudden capture of Mosul, Tikrit and extensive swaths of Iraqi territory has triggered a new crisis, complete with atrocities targeting Iraqi army soldiers and volunteers. Known in Arabic as Da'ash, it grew out of the
} 
defend Islam are mostly foreigners. They are brainwashing victims conducted by ISIS through internet and social media.

The problem that arises that almost every national law provides that every citizen who joins foreign military institutions is automatically loss their citizenship. This rules also applies to Indonesia which embraces the principle of single citizenship. However, the issue that arises is whether ISIS deserves to be called a state in the modern context, because to be called a state there are conditions that must be fulfilled as mentioned in the Montevideo Convention that is a permanent population; a defined territory; government; and capacity to enter into relations with the other states. ${ }^{10}$ The problem that then arises is how to distinguish between combatant and civilian, because both of them have different treatment in war based on international law. ${ }^{11}$

The discourse of the media is considered an interface for the elites to practice social domination as well as the self-appointed voice of the people. Therefore, the press is a powerful institution capable of empowering those that monitor and granting them. ${ }^{12}$ In addition, Todd Green stated 3 (three) causes of Islamophobia: the history of Islamic imperialism, ignorance and poor interaction with Muslims, and the influence of media and government assertion, which generalizes terrorists as Muslims. ${ }^{13}$ Therefore, ignorant people accept these negative stereotypes and tend to dislike Muslims.

The media plays a significant role in Islamophobia by creating negative stereotypes. Although, in essence, it aids in the protection of human rights. This paper focuses on analyzing the role of the media in reporting negative news on Islam as well as the spread of Islamophobia. In addition, this reality ultimately tends to support the government's repressive efforts, thereby ignoring human rights principles.

Islamic State in Iraq, an al-Qaida affiliate which, in turn, came into existence after the 2003 US-led invasion. This group has been given the title of "terrorist organization" by the United Nations, European Union, the United States, Saudi Arabia, and many others. The leader or emir (prince) of ISIS is a 43-year-old Sunni, known by his nom de guerre as Abu-Bakr al-Baghdadi, or Abu Dua. His real name is Awwad Ibrahim Ali alBadri al-Samarrai. He was held prisoner by US forces from 2005 to 2009. According to some accounts he was radicalised by his experience of captivity. But others describe him as having been a firebrand preacher under Saddam Hussein's rule. He studied at the University of Baghdad, and was listed as a terrorist by the UN in 2011. See on, Kumar, Chanchal. "Islamic State of Iraq and Syria (ISIS) a Global Threat: International Strategy to Counter the Threat." Journal of Social Sciences and Humanities 1, No. 4 (2015): 346; Bunzel, Cole. From Paper State to Caliphate: The Ideology of the Islamic State, The Brookings Project on U.S. Relations with the Islamic World. Analysis Paper No. 19, March 2015, p.3

10 Jawahir Thontowi, "Hukum Internasional Kontemporer," (Bandung: Refika Aditama, 2008), p. 105.

11 Yordan Gunawan, "Arbitration Award of ICSID on the Investment Disputes of Churchill Mining PLC v. Republic of Indonesia," Hasanuddin Law Review 3, no. 1 (2017): 14-26.

12 Saad Boulahnane, "Ground Zero Mosque in the Context of America's Post-9/11 Religious Pluralism: CDA of Mainstream News Media's Coverage of the Discursive Event," Indonesian Journal of Islam and Muslim Societies 8, no. 2 (2018): 253-80.

${ }^{13}$ Feldman, Shelly. 2016. "Islamophobia: the causes, consequences, and why we should care". Retrieved from: https://www.theodysseyonline.com/islamophobia-the-causes-consequences-and-why-we-shouldcare 


\section{Method}

This is normative-legal research which applied a case study, comparative, and conceptual approaches. ${ }^{14}$ The data were evaluated with descriptive qualitative and content analyses. Furthermore, words rather than numbers were used as data for analysis. This phenomenon is observable; therefore, the approach used is observation and interpretation. ${ }^{15}$ This paper provides information on the most recent trend of this research. ${ }^{16}$

\section{Mainstreaming Islamophobia: Shift in Media Values as the as Guardian of Human Rights}

Islamophobia has been in existence since the era of Prophet Muhammad SAW, although it was not a global issue. Nevertheless, the recent dynamics have made it a widely trending headline. Principally, Islamophobia is a situation where Islam is subjected to negative occurrences and needs to be feared and disliked, thereby making it seem legal to restrict its movement because it poses a threat. At least certain aspects of history led to Islamophobia, which is a frightening phenomenon for many people.

The first incident was when Omar Mukhtar waged a valiant resistance to the Italian troops in Libya. Irrespective of the fact that Omar was defeated, Omar's heroism and prowess as tagged "Lion of the Desert"17 which was then filmed drew public attention. The second occurrence was during the revolution in Iran. Even though a case was made reporting that the 1979 Iranian Revolution intensified the negative representation of Islam and Muslims in the West, particularly in the US, nevertheless, the scope of the demonization emerged on a different scale during the post-Cold War era. In the UK, Islamophobia is traced to the Iranian revolution and the Salman Rushdie affair, which brought about an intense focus on the Muslim community due to the perceived support of Ayatollah Ruhollah Khomeini's fatwa demanding for Rushdie's assassination. Certainly, political leadership and the media's discourses during that era were filled with anti-Muslim rhetoric, which drew a distinction between Iran (representing a feared aspect of Islam) and the West. ${ }^{18}$

In Indonesia, the Pangeran Diponegoro in Central Java ignited the spirit of resistance against the Dutch invaders, and this caused anxiety among them. Diponegoro was captured in 1830 and was exiled to Manado, a northern city in Indonesia. In South Sulawesi, a militant struggle was led by an Islamic cleric, Sjech Yusuf, from Gowa.

\footnotetext{
${ }^{14}$ Peter Mahmud Marzuki, Penelitian Hukum Normatif, Jakarta: Kencana Prenada Media Group, 2010, 35.

15 Wolff-Michael Roth, Rigorous Data Analysis: Beyond "Anything Goes" (Springer, 2015).

16 Shao-Hsun Keng, "Handout Research Topic Development," Collage of Management, National University of Kaohsiung, Taiwan, 2017.

17 Syukri Rizki and Jelena Golubović, "An Analysis of Speech Act of Omar Mukhtar's Utterances in Lion of the Desert Movie," Englisia: Journal of Language, Education, and Humanities 7, no. 2 (2020): 195-210.

18 Hatem Bazian, "Islamophobia, 'Clash of Civilizations', and Forging a Post-Cold War Order!," Religions 9, no. 9 (2018): 282.
} 
However, in 1699 the cleric was banished and exiled by the Dutch to Cape Town in South Africa. ${ }^{19}$

The apex was 9/11, when the media made unimaginable massive impressions in America, Europe, and the entire world, for days and even months. The repetition of the scenes of planes crashing into the twin towers WTC increasingly triggered Islamophobia in globally. The search for victims, and the grievance of families, hurt the general public. The arrest of the alleged terrorist and the evil plan's disclosure caused an increase in hatred and Islamophobia. There are 2 (two) facts that appeared in the reportage of terrorism incidents by the media. Firstly, they continuously reported the incident and also wisely tried to calm public emotions. Secondly, the media reported facts, as well as fueling the anger on the minds of the organizers of the news, starting from reporters to the editors. For example, during any form of terror by an Islamic group, the reportage carried out by Al-Jazeera is undoubtedly different from CNN. In addition, the reportage by the FOX television network is even more bizarre. This aspect of the media is referred to as framing in terms of communication terms or agenda-setting.

The news concerning what happened in Palestine always felt bias. For example, when the Israeli soldiers carry out brutal attacks on Palestinians - including children and women, the media usually refer to them as "Israeli Attacks," despite conducting these activities with sophisticated and extraordinary weapons. In contrast, a different headline is reported assuming the attack is carried out by Palestinians. They usually emblazoned the words "Terrorist Attacks." The Western media reported the attack on the Iranian General Qasem Soleimani by the United States using missiles at the Baghdad airport in early January 2020, killing the commander of the Quds Wing of the Iranian Revolutionary Guards. Irrespective of the brutal American attack, the substance of the news sank with the issue that Qasem Soleimani was the figure behind the terrorist acts in many regions. The attack was ordered by Trump, stating that it was to stop the impending war planned by Soleimani.

The media accepts "Trump's explanation" relating to the killing and considers it an ordinary event; however, this is an example of the media, deviating from its essence, although the American-Democrats criticized this attack. The Chair of the Foreign Relations of the US' House of Representatives Eliot Engel stated that the congress was not consulted on the General's attack. The headlines displayed by the American media, such as "Trump: Soleimani's reign of terror is over," "Trump: Soleimani was a monster." Trump even posted a tweet, "General Qassem Soleimani has killed or badly wounded thousands of Americans over an extended period, and was plotting to kill many more...but got caught!"

The American and European media tend to ignore their moral essence of protecting human rights on several occasions, particularly when these attacks are conducted by Islamic terrorist groups. The United States and its ally's attack, under the pretext of curbing terrorist centers that have destroyed various countries in the Middle East, namely Iraq, Libya, Syria and Afghanistan, and media reportage, usually exclude several

\footnotetext{
${ }^{19}$ Saarah Jappie, "'Many Makassars': Tracing an African-Southeast Asian Narrative of Shaykh Yusuf of Makassar," in Migration and Agency in a Globalizing World (Springer, 2018), 47-66.
} 
massacres that occurred during these raids. The destruction of the center of Islamic civilization, which disrupted the peaceful lives of innocent citizens, has become a spectacle of media reportage without any criticism.

The media ignored the misfortune and destruction of humanity, which occurred in various regions. They were already contaminated with "revenge" for the actions of terrorists that were not part of the Muslim community, promoting peace. Islamophobia has restrained the minds of media managers in the West, including ignoring 9 elements of journalism as indoctrinated by Bill Kovach and Tom Rosenstiel. ${ }^{20}$ One of the elements states that journalists need to listen to their conscience. Therefore, it is strongly believed that the journalist's conscience does not permit slaughtering of any name. They have the right to be angry over the cruelty of a group of terrorists; however, they also do not encourage any country to slaughter and destroy humanity.

Sean Illing, ${ }^{21}$ stated in an article published on the $20^{\text {th }}$ of December, 2018 titled "Intellectuals have reported that democracy has been failing for a century," that they were wrong. According to the book "Public Opinion" by Walter Lippmann published in 1922, the most persuasive critique of democracy was revisited. Illing stated that Lippmann' concepts remain prominent and relevant to date. The press is similar to a wandering spotlight, bouncing from one topic to another, story to story, illuminating several events, and never fully explaining them. According to Illing, the primary objective of news agencies is to signify an event, expose the hidden facts, and state the relationship between them in order to create a picture of the reality in which humans tend to act.

By its essence, the press needs to imbibe the morals to uphold the truth. They need not be biased, particularly to manipulate a fact out of disproportion even when the public does not desire the "truth," like Islamophobia, which has already gripped the minds of several people in the West. Illing reported that Lippmann undermined an assumption baked into most democratic theories, stating that the press is expected to "carry the entire burden of popular sovereignty" by informing the truth even though it's not at all clear of people are interested in truth. The press is a derivative of freedom and the enforcement of human rights. It was created with the intent to voice and maintain freedom as well as protect human dignity. Additionally, it relates to the enforcement of human rights. The press has the same innate character as humans, namely freedom. ${ }^{22}$

Experts assume human rights are inherent in nature. The understanding of human nature is not viewed abstractly. However, all its dimensions are concerning God, society, and the natural environment. Humans tend to develop themselves according to their dignity perfectly. Irrespective of the fact that an institution or State regulates the rights concerning freedom, it is intended to monitor the ideas to avoid conflict of interests in the people, kingdom, or State as a larger institution. Furthermore, the State does not act

\footnotetext{
${ }^{20}$ Kovach, Bill \& Rosenstiel, Tim, the elements of journalism: What news people should know, and the public should expect. New York: Three Rivers Press (CA), 2014, 43-46

${ }^{21}$ Sean Illing, (2018). "Intellectuals have said democracy is failing for a century. They were wrong. Walter Lippmann's famous critique of democracy revisited". Retrieved from: https://www.vox.com/2018/8/9/17540448/walter-lippmann-democracy-trump-brexit.

22 Asbjørn Eide, Catarina Krause, and Allan Rosas, Economic, Social and Cultural Rights: A Textbook (Brill, 2001), 12.
} 
arbitrarily in its regulation before delivering it to the press. The media serves as a guide to maintain freedom and human rights. This message was also conveyed by Walter Lippman, a prominent American journalist, and political thinker. According to Walter, the government is a product of democracy that serves people's welfare, and it needs to be controlled by another democratic product, namely, Parliament when exercising its power. In addition, the Press acts as a democratic tool that controls the power exercised by the government due to its ability to deviate and harm people.

Freedom is an important part of the UN with the1948 Declaration of Human Rights. However, freedom of the press started in Western countries, such as America, after the founding fathers in the $17^{\text {th }}$ century realized that the constitution was not strong enough to protect their citizens. Based on that, the United States of America issued the First Amendment, which became phenomenal rules for freedom of the press and the main basis for the implementation of human rights. This Amendment stated that congress does not need to make any law regarding the establishment of religion, or prohibiting freedom of speech by the press (The First Amendment: 1791). ${ }^{23}$ However, Thomas Jefferson (1816) stated that the desire to provide total freedom for the press is not free from challenges, although it tends to release Americans from ignorance. Furthermore, this activity protects their democracy, thereby, making it impossible to choose a country without newspapers. Thomas Jefferson's famous statement was, "...assuming it was left to me to decide whether we should have a government without or with newspapers, I wouldn't hesitate a moment to prefer the latter."

The above phenomenon was later proven to have made press freedom as a guardian of American democracy and glory. The State that provides freedom to the press is part of civilization, which considers its people's conscience. The society is actually in need of freedom in any space, especially the press, as long as it does not interfere with their life. The freedom of press in Europe has also become an important part of the progress of their democracy and enforcement of human rights. America and other countries that place freedom of press and media as the main pillars are dignified countries. The media becomes the watchdog of the nation and continues to work to guide the people and their government towards achieving predetermined goals in the right direction. This view was expressed by Ganendra N. Ray, a senior Indian judge who later chaired the Press Council of India. Since the media plays the role of communication between the state and the public, it can also play an effective role in making the authorities aware of their duties. Currently, it aims to report, analyze, and comment on the political affairs of a country, with challenges in protecting human rights. ${ }^{24}$

However, it does not ignore news related to terrorism, for instance, when the Iranian Revolutionary Guards occupied the US' Embassy in Tehran Iran and detained some staff. The hostage drama's time span was an interesting reportage for the print and electronic media to report. This includes reports on the angry demonstrators outside the Embassy building and the family members' responses to those held hostages. Unfortunately,

\footnotetext{
${ }^{23}$ Human Rights Reference Handbook, Netherlands Ministry of Foreign Affairs, Brussels, 1992, 45.

${ }^{24}$ G N Ray, "The Role of Media in Protection of Human Rights" (Visakhapatnam: Human Rights Council, 2007), 7.
} 
because it occurred in an Islamic country and was perpetrated by a Muslim group, it leads to an increase in "Islamophobia."

\section{Civilian who became Combatant in Abroad}

One of the problems that recently emerged was the phenomenon of many civilians who became combatants abroad. This phenomenon is due to the development of digital information that increasingly makes the boundary between one country with other countries increasingly not distant. Brainwashing process that previously had to go through face to face and through a long and systematic process, now can be done by anyone and anyone can become the victim. This condition triggered a new problem in international law. Since in the first place, these combatants are civilians, they are citizens who are not legally required to fight in the territory. Indeed, the definition of combatant is very clear and universal, for anyone who fought in the area then he called combatant. But what if they then declare back to their home country for certain reasons? What is their status?

A civilian may convert himself into a combatant. In fact, every combatant is a former civilian: nobody is born as a combatant. In the same vein, a combatant may retire and become a civilian. But a person cannot (and is not allowed to) be both a combatant and a civilian at the same time, nor can he constantly shift from one status to the other. ${ }^{25}$ International law provides that any combatant be able return to civilian with certain conditions. According to A. Rosas, the combatant who wants to become a civilian must be treated like a prisoner of war. In international law, the subject is called hors de combat. Based on the 1949 Geneva Conventions, unlawful combatants hors de combat is granted the same privilege and to be treated with humanity while in captivity but unlike lawful combatants, they are subject to trial and punishment, which includes capital punishment. Based upon article 41- Safeguard of an enemy hors de combat, A person who is recognized or who, in the circumstances, should be recognized to be hors de combat shall not be made the object of attack.

In international law perspective, the combatants who then want to return to civilian must be protected and treated the same as other prisoners of war. The concept of positioning is the same as other prisoners of war, not in order to punish it but to keep the detainee from re-engaging in military-related activities. The problem that then sprung up was the combatant who later became the civilian then returned to a country which did not take part in the war. This, of course, will indirectly strike between national law and international law. But what is the position of international law in the state? International law and national law have unique relations.

\footnotetext{
25 Yoram Dinstein, The Conduct of Hostilities under the Law of International Armed Conflict (Cambridge University Press, 2016), 28.
} 
There are two veins from law experts in seeing the relationship between national law and international law. First, it is the flow of monism that figure out the position of international law and national law as an inseparable unity, as Kelsen said: ${ }^{26}$

Since the international legal order not only requires the national legal orders as a necessary complementation, but also determines their sphere of validity in all respect, international and national law form one inseparable whole.

That opinion reinforces Kelsen's view of unity as a whole between national law and international law. That is why international law and national law are an integral whole and cannot entirety. As a further form of explanation, Kelsen in his view stated "... the fact that state as acting persons are organ international law, or the community constituted by it. The very clear attitude of the state is the international organ and the international community established by the state. Therefore, according to Kelsen, "the creation and execution of an order are the functions of its organ and the international legal order is created and executed by state". It is clear that the international legal base for Kelsen is the state and "it is from standpoint of international law that its connection with national law and hence with a universal legal order is seen.

The above-mentioned Thesis Kelsen directly points to the position of national law as the basis of validity in the hierarchy of norms for international law. The placement of national law as the main subject of international law appears to be influenced by Kelsen's own positivist thinking which understands the existence of the state as a sovereign legal organization, the organizer of power, and through its organs administering the rule of law. On the basis of national laws, a country deals with other countries and vice versa. Therefore, the norm of international law according to Kelsen is an incomplete norm and becomes perfect after being approved by the norm of national law. Besides the monism with the primacy of national law, there is also the type of monism with the primacy of international law. This view brings the state in intrinsic relation to international law and hence, all the elements of the state are determined by international law.

The problem that then arises is the presence of the state in an international convention cannot be separated from the sovereignty of national law that allows for it. So that the basis of the formation of international agreements is none other than the national law respective individual countries, so that even if a country is subject to the agreement is inseparable from the national law of each country which became the basis of its validity in formalizing international law. Therefore, the problem of how to respond to the combatant who later returned to civilian and back to their respective countries can not solely be based on international law, but must also heed the national law. How does the national law regulate the provisions?

\footnotetext{
351.

${ }^{26}$ Hans Kelsen, "General Theory of Law and State (New Brunswick, NJ" (Transaction Publishers, 2006),
} 


\section{Islamophobia and the War on Terrorism}

Across the Islamic world, the radical philosophies that led to lots of death and destruction were ideological, political, and religious. Similar to the religious fervor, which had driven human conflicts for millennia, Islamophobia also influenced America and the West more broadly. Most importantly, this was not a war on making Afghanistan, Iraq, Syria, or any other country nicer or safer places to live. According to Marxist analysis, a better economic way of life tends to divert people from terrorism. This analysis was conducted to keep America safe from another 9/11, or a worse attack, with the use of nuclear, chemical, or biological weapons by terrorists. Therefore, as long as the threat existed, Americans were worried because they were certain the terrorists were coming on wooden sailing ships. ${ }^{27}$

According to John Bolton, on August 20, President Trump called to inform Israel to inquire about a shooting that occurred in the early hours of the day, near the US embassy in Ankara. John stated that the incident was a local criminal, unrelated to the US authorities in Israel. Nonetheless, the President thought of closing the embassy, thereby increasing the heat regarding Brunson, or canceling Turkey's F-35 contract. John stated that he called Pompeo and other security personnel to inform them of the President's decision and asked the NSC staff to consider the available options. Pompeo believed that Turkey's Ambassador is declared "persona non grata".

During this period, there were tensions between Turkey and the United States regarding the detention of an American priest Andrew Brunson. Turkey sued Brunson for the terrorism-related accusation that US officials considered ridiculous. Trump continued to communicate with the Turkish President Recep Tayyip Erdogan. On the same day, Turkey announced that the shooting was an attempt to "create chaos," with the arrest of two civilians over the incident.

The media editorial policy that raised Islamophobia eventually tended to support Western governments' repressive efforts to destroy centers suspected to be terrorist dens. They aimed to destroy Iraq, Syria, Afghanistan, Yemen and Iran, while ignoring human rights principles. Similarly, on December 11, 2018, a French-born Algerian man named Cherif Chekatt (29 years) attacked a night market visitor in Strasbourg, France. This gruesome act occurred in front of the Strasbourg Cathedral, with the culprit identified as a minor that has committed over 67 crimes since the age of 10 in France, Switzerland, and Germany. That night, Cherif used a gun and a knife to kill 5 people, leaving 11 others with serious injuries. The culprit immediately fled from the scene but was shot dead two days later. Police announced that Cherif was linked to the Islamic State of Iraq and the Levant (ISIL) network.

A week later, Erik Bleich and A. Maurits Van der Veen in the Washington Post of 20 Dec 2018, quoted the incident and wrote an article entitled, "Newspaper coverage of Muslims associated with terrorism." 28 Erik explained that once there was a violent attack by a Muslim, the print and electronic media is filled with a variety of reportage and

\footnotetext{
27 Ibid.

28 Bleich, Erik; van der Veen, Maurits. "Newspaper coverage of Muslims is negative. And it's not because of terrorism". The Washington Post. Dec 20, 2018 edition.
} 
conversation related to "Islam and violence." According to many observers, this is typical and adds to the belief of many people that reportage related to Muslims, especially those related to violence, is always negative.

Since the 9/11 attack, newspapers in the United States have always linked Islam with negative attributes, even when the writings are not related to terrorism and extremism. However, articles related to Catholics, Jews, and Hindus consists of positive attributes. Bleich and Veen try to measure these negative attributes associated with Islam by using negative and positive words, such as: "attack" or "beautiful."

In general, Bleich and Veen stated that more negative words in an article lead to affect people's perspectives regarding a religion adversely. They took samples from various papers published in the United States between 1996 and 2015 with a baseline for "neutrality" to determine the average tone of a representative sample of more than 48,000 articles. Furthermore, they collected more than 850,000 articles published in these same years by searching the database using the keywords "Muslim" or "Islam" in 17 national and regional newspapers. The keywords "Catholic," "Jewish" and "Hindu" were also used to conduct a comparative analysis amongst these religions.

Approximately 236,000 articles were collected related to Islam, and more than 352.000 , 245.000, and 19.000 each were obtained on Catholics, Jews, and Hindus religion. The newspapers selected by Bleich and Veen were The Washington Post and Wall Street Journal. Both categories are national newspapers that represented several stated with the addition of the Richmond Times-Dispatch and the Denver Post, as well as tabloids, which include the New York Post and the New York Daily News. The results of this analysis are shown in Chart 1.

According to this study, approximately 78 percent of the articles in Islam comprised of negative contexts, while the remaining 22 percent were positive. However, the articles regarding Catholics, Jews, and Hindus religion, only had 40, 46, and 49 percent negative attributes.

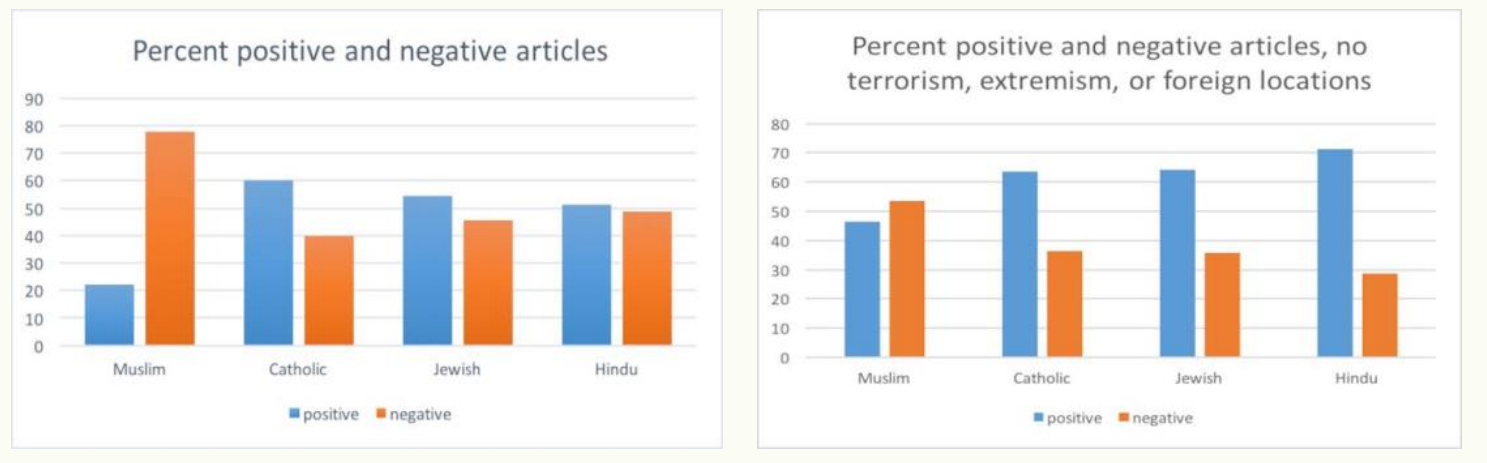

Chart 1. Comparative analysis amongst the religions in media coverage.

Bleich and Veen also carried out research to filter stories on terrorism and extremism. They both analyzed articles related to Muslims without references to terrorism or extremism. Out of the total number of articles, 54 percent were negative, compared to only 37, 36, and 29 percent related to Catholicism, Jews, and Hinduism. The figures showed that all news on terrorism and attacks are associated with Muslims. For example, 
the controversy of the Ground Zero Mosque event through the imbalanced sourcing strategy and was associated with negative attributes such as terrorism, extremism, Hamas, Sharia, Jihad, etc. Despite the non-violent nature of the news, media coverage channeled the event through an anti- Muslim agenda, resulting in the vivid altering of the Islamic community in the United States and the intensified ambiguity characterizing the American religious pluralism. ${ }^{29}$

The media acts as a democratic platform used to guard human rights. However, it has turned out to be at a crossroads to test its consistency with reports related to violence, terror, and its aftermath used to conduct its duty and mission. It tends to report the various activities that occur with the intention that the incident does not re-occur, by ensuring that the State administrators provide a solution to these problems by increasing their vigilance. Some media actors tend to provide reports on violence action, terror, and their aftermath with "anger" and "hatred" against the perpetrators and their religion. Therefore, it is ideal for the media to maintain its independence, neutrality, and attitude as a "guardian" of democracy and the enforcement of human rights. Furthermore, people without religious sentiments and national patriotism to avoid discrimination, exclusion, and prejudice need to be managed by people without religious sentiments.

\section{Conclusion}

Islamophobia currently exists with strong growth in Western society and some countries with a minor Muslim population. This activity creates an atmosphere with a scourge for decision-makers in many countries with numerous attributes associated with its growth. Some of the effects of violence, terrorism, and others by a group of Muslims led to an increase in discrimination, and exclusion. This was generally experienced in many Western countries; therefore, the media or State need to analyze and determine the various factors increasing the act of violence. As the guardian of human rights and democracy, the media need to balance the principle of conscience and essence in carrying out its functions. This is because the press was born from the intention to voice and maintain freedom and protect other human dignities. However, at the practical level and supported by the available facts, it turns out to be at a crossroads, thereby betraying the essence of its existence. The media sometimes becomes discriminatory due to fanaticism, violence, and terror in many extreme religious groups. For this reason, as an extraordinary crime, terrorism requires extraordinary handling. Civilians who become combatants in a foreign country become a new case in international law, because there has never been a similar case before. In Indonesian law, this issue has not been regulated in the applicable law, it causes these combatants when they return to Indonesia cannot be punished.

\footnotetext{
29 Boulahnane, Saad, 2018, Loc. Cit.
} 


\section{References}

Allen, Christopher. Islamophobia. Surrey: Ashgate Publishing Ltd Juergensmeyer, Mark. 1994. The New Cold War? Religious Nationalism Confronts the Secular State. London: University of California Press Ltd, 2010.

Bazian, Hatem. "Islamophobia,'Clash of Civilizations', and Forging a Post-Cold War Order!" Religions 9, no. 9 (2018): 282.

Boulahnane, Saad. "Ground Zero Mosque in the Context of America's Post-9/11 Religious Pluralism: CDA of Mainstream News Media's Coverage of the Discursive Event." Indonesian Journal of Islam and Muslim Societies 8, no. 2 (2018): 253-80.

Bunzel, Cole. From Paper State to Caliphate: The Ideology of the Islamic State, The Brookings Project on U.S. Relations with the Islamic World. Analysis Paper No. 19, March 2015.

Dinstein, Yoram. The Conduct of Hostilities under the Law of International Armed Conflict. Cambridge University Press, 2016.

Eide, Asbjørn, Catarina Krause, and Allan Rosas. Economic, Social and Cultural Rights: A Textbook. Brill, 2001.

Feldman, Shelly. 2016. Islamophobia: the causes, consequences, and why we should care. Retrieved from: https://www.theodysseyonline.com/islamophobia-the-causesconsequences-and-why-we-should-care

Garrett, Peter Donald, and Allan Bell. "Media and Discourse: A Critical Overview," 1998.

Gunawan, Yordan. "Arbitration Award of ICSID on the Investment Disputes of Churchill Mining PLC v. Republic of Indonesia." Hasanuddin Law Review 3, no. 1 (2017): 1426.

Hapsari, Renitha Dwi. "Islamophobia Dan Tindakan Terhadap Minoritas Muslim Oleh Pemerintah Dan Kelompok 969 Di Myanmar Tahun 2012-2016." Global and Policy Journal of International Relations 4, no. 02 (2016).

Hart, Michael H. The 100: A Ranking of the Most Influential Persons in History. Citadel press, 1978.

Jappie, Saarah. "Many Makassars': Tracing an African-Southeast Asian Narrative of Shaykh Yusuf of Makassar." In Migration and Agency in a Globalizing World, 47-66. Springer, 2018.

Kellner, Douglas. Media Spectacle and the Crisis of Democracy: Terrorism, War, and Election Battles. Routledge, 2015.

Kelsen, Hans. "General Theory of Law and State (New Brunswick, NJ." transaction publishers, 2006.

Keng, Shao-Hsun. "Handout Research Topic Development." Collage of Management, National University of Kaohsiung, Taiwan, 2017.

Kovach, Bill \& Rosenstiel, Tim. The elements of journalism: What news people should know, and the public should expect. New York: Three Rivers Press (CA), 2014.

Kumar, Deepa. "Framing Islam: The Resurgence of Orientalism during the Bush II Era." Journal of Communication Inquiry 34, no. 3 (2010): 254-77. 
Lean, Nathan Chapman, and John L Esposito. The Islamophobia Industry: How the Right Manufactures Fear of Muslims. Pluto Press London, 2012.

Mahmud Marzuki, Peter. "Penelitian Hukum Normatif." Jakarta: Kencana Prenada Media Group, 2010.

Ray, G N. "The Role of Media in Protection of Human Rights." Visakhapatnam: Human Rights Council, 2007.

Rizki, Syukri, and Jelena Golubović. "An Analysis of Speech Act of Omar Mukhtar's Utterances in Lion of the Desert Movie." Englisia: Journal of Language, Education, and Humanities 7, no. 2 (2020): 195-210.

Roth, Wolff-Michael. Rigorous Data Analysis: Beyond "Anything Goes." Springer, 2015.

Sean Illing, 2018. "Intellectuals have said democracy is failing for a century. They were wrong. Walter Lippmann's famous critique of democracy revisited". Retrieved from: https://www.vox.com/2018/8/9/17540448/walter-lippmann-democracytrump-brexit.

Sultan, Khalid. "Linking Islam with Terrorism: A Review of the Media Framing since 9/11." Global Media Journal: Pakistan Edition 9, no. 2 (2016): 1-10.

Thontowi, Jawahir. Hukum Internasional Kontemporer. Bandung: Refika Aditama, 2008.

Conflict of Interest Statement: The author(s) declares that the research was conducted in the absence of any commercial or financial relationship that could be construed as a potential conflict of interest.

Copyright: (C) HALREV. This is an open access article distributed under the terms of the Creative Commons Attribution 4.0 International License (CC-BY 4.0), which permits unrestricted use, distribution, and reproduction in any medium, provided the original author and source are credited.

Hasanuddin Law Review (Hasanuddin Law Rev. - HALREV) is an open access and peer-reviewed journal published by Faculty of Law, Hasanuddin University, Indonesia. 